\title{
Avisaje farmacéutico en la Revista Médica Herediana
}

\author{
Pharmaceutical announcing in medical journals
}

En primer lugar quiero expresar mi más efusiva felicitación por la Revista Médica Herediana. Su presentación es impecable y la calidad de los trabajos es una demostración de nivel académico alcanzado en nuestro medio. Me siento, como médico peruano y como parte integrante de la revista, genuinamente orgulloso.

En una publicación científica de esas calidades resulta paradójico que las compañías farmacéuticas exhiban un avisaje falto de ética. La Revista Médica Herediana no merece una afrenta como esa.

El artículo 160 del Código de Ética y Deontología del Colegio Médico del Perú prohíbe expresamente "....cualquier tipo de exhibición y propaganda, no rigurosamente científica o que se preste a la difusión de hechos no respaldados por investigación científica seria...”

Hace tiempo que ando en busca de información veraz y científica sobre las reales propiedades farmacológicas del butil bromuro de hiosina. En todas las farmacopeas que he consultado sólo aparece la forma metil bromuro de este producto. No comprendo las razones farmacológicas de la empresa Boehringer Ingelheim para elaborar este producto de tan extendida comercialización, entre nosotros, sin dar los indispensables detalles sobre su uso racional. Además tengo dudas sobre la dosis tóxica y la terapéutica del mismo. Como está descrito para el caso del metilbromuro, en los que ambas dosis tienen un margen muy estrecho. Quisiera, por otro lado, conocer algo más de la Buscapina Compositum N, anunciada en varios números de nuestra revista. Así, por ejemplo, saber si el jaque mate que aparece en el bello arte es porque el "Compositum N" ya no tiene dipirona. De ser así creo que todos debiéramos estar informados de la naturaleza de esa nueva combinación; y, desde luego, esperar que fuese menos peligrosa que su antecesora.

La firma Upjohn -como lo ha dicho en repetidas oportunidades el profesor de farmacología de la Universidad de California, USA, Milton Silverman- tiene la política de anunciar sus productos con textos distintos. Una cosa nos dice a los médicos peruanos (o de Latinoamérica) sobre las propiedades de sus productos y otra a los médicos norteamericanos. En la contra tapa del Vol $2 \mathrm{~N}^{\circ}$ 1 , de nuestra revista, esta firma se permite anunciar su clorhidrato de clindamicina, sin ninguna advertencia, diciendo a los lectores de nuestra revista que es: "Excelente (para la) cobertura contra estafilococos, estreptococos y la mayoría de los anaerobios". Esa misma empresa en el Physicians' Desk Referente (44 Edition, 1990, página 22111) anuncia a los médicos norteamericanos, en el rubro de indicaciones y usos: que la primera indicación de este antibiótico es "...En el tratamiento de..Infecciones serias causadas por bacterias anaeróbicas". Y como segunda indicación "debe ser usada en infecciones serias por cepas sensibles de estreptococo, neumococo y estafilococo. Su uso debe ser reservado a pacientes alérgicos a la penicilina $u$ otros pacientes en quienes, a juicio del médico, una penicilina es inapropiada. A causa del riesgo de colitis; antes de usar la clindamicina el médico debe considerar la naturaleza de la infección y la disponibilidad de alternativas menos tóxicas (p. ej. Eritromicina)".

Estos son dos ejemplos de los múltiples que se puede comentar de los avisos colocados por la industria farmacéutica nativa. Tengo confianza que los directivos de esta importante actividad han de recapacitar y reaccionar en sentido positivo. 
Una sugerencia, para solucionar esta incongruente situación, es la de solicitar a los fabricantes de medicamentos avisaje científico, si cabe el concepto. De este modo podríamos tener una carilla llena de información basada en datos veraces que nos ilustre sobre los productos farmacéuticos. Así podríamos estar al tanto de las propiedades químicas, descripción, farmacología clínica, indicaciones, usos, contraindicaciones, advertencias, precauciones, reacciones adversas, dosis, vías de administración y formas de presentación. No es posible que la industria farmacéutica utilice técnicas de publicidad, dirigidas a los médicos, como si éstos fueran legos, por decirlo con elegancia.

Dr. Uriel García Cáceres

Profesor de Patología y de Historia de la Medicina 